\title{
Not any two will do: DNA divergence and interpopulation reproductive compatibility in the simultaneous hermaphroditic shrimp Lysmata wurdemanni
}

\author{
Andrew L. Rhyne ${ }^{1,2, *}$, Dong Zhang ${ }^{3,4}$, Junda Lin ${ }^{3}$, Nikolaos V. Schizas ${ }^{5}$ \\ ${ }^{1}$ Department of Biology and Marine Biology, Roger Williams University, One Old Ferry Road, Bristol, Rhode Island 02809, USA \\ ${ }^{2}$ Edgerton Research Laboratory, New England Aquarium, 1 Central Wharf, Boston, Massachusetts 02110, USA \\ ${ }^{3}$ Vero Beach Marine Laboratory, Florida Institute of Technology, 805 46th Place East, Vero Beach, Florida 32963, USA \\ ${ }^{4}$ School of Environmental Science and Public Health, Wenzhou Medical College, Wenzhou 325035, P.R. China \\ ${ }^{5}$ Department of Marine Sciences, University of Puerto Rico, Mayagüez, Isla Magueyes Laboratories, PO Box 9013, Mayagüez, \\ Puerto Rico 00681-9013, USA
}

\begin{abstract}
We studied the molecular population structure of the hermaphroditic caridean shrimp Lysmata wurdemanni (Gibbes, 1850), which is distributed along the east coast of the USA and in the Gulf of Mexico. Four populations within the reported range were sampled: North Carolina (NC), Florida east coast (FLE), Florida Keys (FLK), and Texas (TX). Of the 3 populations of L. wurdemanni tested for interpopulation breeding (FLE, FLK, TX), only the FLE $\times$ FLK cross was successful. Both Florida populations failed to successfully hybridize with the Texas population during the experimental period. Additionally, there appears to be strong directionality between Florida and Texas crosses: when TX females crossed with either male FLK or FLE shrimps, few eggs were present and no larval hatching occurred, whereas crosses between FLE or FLK females and TX males produced embryos, but no viable larvae were produced during the experimental period. Genealogical analyses of the mitochondrial genes cytochrome oxidase subunit I (COI) and the large subunit of ribosomal RNA (16S rRNA) genes yielded distinct and highly supported clades for each of the FLE, FLK, and TX populations. High pairwise $F_{\text {ST }}$ values between TX versus FLK, TX versus FLE, and FLK versus FLE suggested that the populations are genetically disconnected. The NC and FLE populations could not be distinguished phylogenetically. This is an example of a marine species for which the potential for larval dispersal is predominantly unrealized given the observed absence of gene flow and the strong reproductive isolation between populations on the southeast coast of the United States and on the Gulf coast.
\end{abstract}

KEY WORDS: Lysmata wurdemanni - Population connectivity - Reproductive compatibility · Interbreeding $\cdot$ Caridean shrimp Resale or republication not permitted without written consent of the publisher

\section{INTRODUCTION}

The amount of gene flow between populations is considered to be relatively proportional to the dispersal ability and geographic range of the organisms involved (Bohonak 1999, Lester \& Ruttenberg 2005). For sessile marine invertebrates (fixed and those with a limited home range), the only effective means of dispersal is a planktonic larval stage. Thus, benthic species (those that do not undergo large migrations) are distributed in patches that can only be connected by planktonic larvae. Species that have long larval periods were thought to have extended geographic distributions and associated high levels of gene flow when compared to species 
with shorter larval durations (Shuto 1974, Jablonksi 1986). Those marine species with extended planktotrophic life cycles have been thought of as open populations, with regular or intermittent occurrences of gene flow from surrounding populations.

The amount of time larvae spend in the water column can vary dramatically within or across families and even within the same genus. This has provided contrasting examples of larval dispersion and biogeography within very closely related species (Kinlan \& Gaines 2003, Bird et al. 2007, Kelly \& Eernisse 2007). These studies have provided growing evidence that discounts the notion that long-lived planktonic larvae can be equated with broad dispersion and the absence of genetic structure across their geographic range. Populations that appear similar may in fact be distinct isolated populations of the same species or complexes of cryptic species (Knowlton 1993, Palumbi 1994). For example, Lee \& Foighil $(2004,2005)$ examined the genetic structure of the scorched mussel Brachidontes exustus and established that 'populations' of this species were in fact a complex of species throughout its historical geographic range. Lee (2000) examined the global phylogeography of the copepod Eurytemora affinis and demonstrated with mitochondrial DNA and interpopulation mating experiments that the presumed uniformly distributed species was in fact several reproductively isolated sibling species. After detailed morphological examination, genetic lineages of the copepod Cletocamptus deitersi (see Rocha-Olivares et al. 2001) also proved to be different species (Gómez et al. 2004). This was illustrated in the case of the whelk Busycon perversum as well, which is associated with high divergence between the Florida Atlantic and Gulf of Mexico populations. These populations are now considered sister taxa (Wise et al. 2004). Genetic divergence between marine populations may evolve as a result of intrinsic factors, extrinsic factors, or their interaction (Hilbish 1996). Divergence between populations may be maintained in the presence of selection. Sotka et al. (2004) suggested that, while populations of the barnacle Balanus glandula should be connected by dispersal alone (over a geological time scale), there is a strong likelihood that selection influences the patterns of genetic variation in populations and causes the sharp differences between northern and southern populations. Ocean currents and physical processes may indeed act as physical barriers promoting speciation. Selection for a specific genotype would further magnify this effect (Hilbish \& Koehn 1985, Schizas et al. 2001). These genetic patterns have been mirrored in terrestrial environments, where physical barriers lead to localized extinction of haplotypes in widely distributed allopatric species, with differences only detectable at the genetic level (Vogler \& DeSalle 1994, Barber 1999).
Among decapod crustaceans, several studies have focused on the genealogy of populations and the phylogeny of closely related taxa. The best known are those dealing with transisthmian pairs of snapping shrimp (Alpheus). Knowlton et al. (1993) reported divergence in the mtDNA cytochrome oxidase subunit I (COI) gene among 7 pairs of Alpheus species across the Isthmus of Panama to be between 6.6 and $19.2 \%$, with reproductive isolation, but not behavioral isolation, occurring in all but 1 replicate of the transisthmian crosses. In contrast, crosses between pairs of Alpheus species from the same ocean produced fertile clutches $60 \%$ of the time. It was inferred that reproductive isolation requires $>6.6 \%$ divergence in COI sequences, or 4.5 to 5 million years of isolation, if the revised rates for divergence (1.4\% per $10^{6}$ years) across the Isthmus of Panama are used (Knowlton \& Weigt 1998). Mathews et al. (2002) found divergence of 2 to $5 \%$ between 2 closely related species of Alpheus shrimps. Later, Mathews (2006) examined 16S sequences of the Alpheus shrimp over a wide geographic area and established distinct isolated populations and/ or cryptic species.

While the separation of 2 bodies of water by a land mass is an obvious reproductive barrier for marine species, oceanographic features may also pose severe restrictions on a species' ability to disperse. In addition to physical dispersal barriers, a few studies have experimentally demonstrated an unexpectedly high amount of local recruitment among species with extended larval development. This has been reported in Alpheus (see Knowlton \& Keller 1986) and in some reef fish (Jones et al. 1999, Taylor \& Hellberg 2003). Both biotic and abiotic factors can influence localized recruitment (Almany et al. 2007), e.g. larval behavior (Burton \& Feldman 1982), temperature gradients (Wares et al. 2001) and ocean currents (McConaugha 1992, Baums et al. 2006) have been implicated in the restriction of larval dispersal.

As our study species we chose Lysmata spp.; these are small caridean shrimps that occupy wide geographic ranges and diverse ecological habitats (Bauer 2004). They differ from nearly all other decapods by having an unusual reproductive mode, protandric simultaneous hermaphroditism. Lysmata shrimp first develop as males and then may change to become a simultaneous hermaphrodite (Bauer \& Holt 1998, Fiedler 1998, Bauer 2000). Within the genus, species delineations can be made on the basis of adult morphology, larval developmental characteristics, and ecological associations. Larvae within the Lysmata genus have been studied relatively well in recent years (e.g. Calado et al. 2005), and development times have been reported to range from approximately 18 to $>160 \mathrm{~d}$ in the laboratory. Like many other caridean shrimp, 
Lysmata may undergo a developmental delay (mark-time molting) (Gore 1985, Anger 2001); if conditions are not appropriate for an extended period of time, development (pre-competency) and settlement (post-competency) can be delayed for well over $30 \mathrm{~d}$ (A. Rhyne pers. obs.).

Until recently, the western Atlantic peppermint shrimp Lysmata wurdemanni was ubiquitous throughout its known range (New Jersey, USA, to Brazil). The species was reported to occupy multiple habitat types from rocky shorelines, hard-bottom reefs, tube sponges, to shell bottoms within inlets. However, a recent taxonomic revision (Rhyne \& Lin 2006) identified 4 new species of Lysmata and clarified the distributional ranges for 6 species of western Atlantic Lysmata. Of these, $L$. wurdemanni was restricted to the Gulf

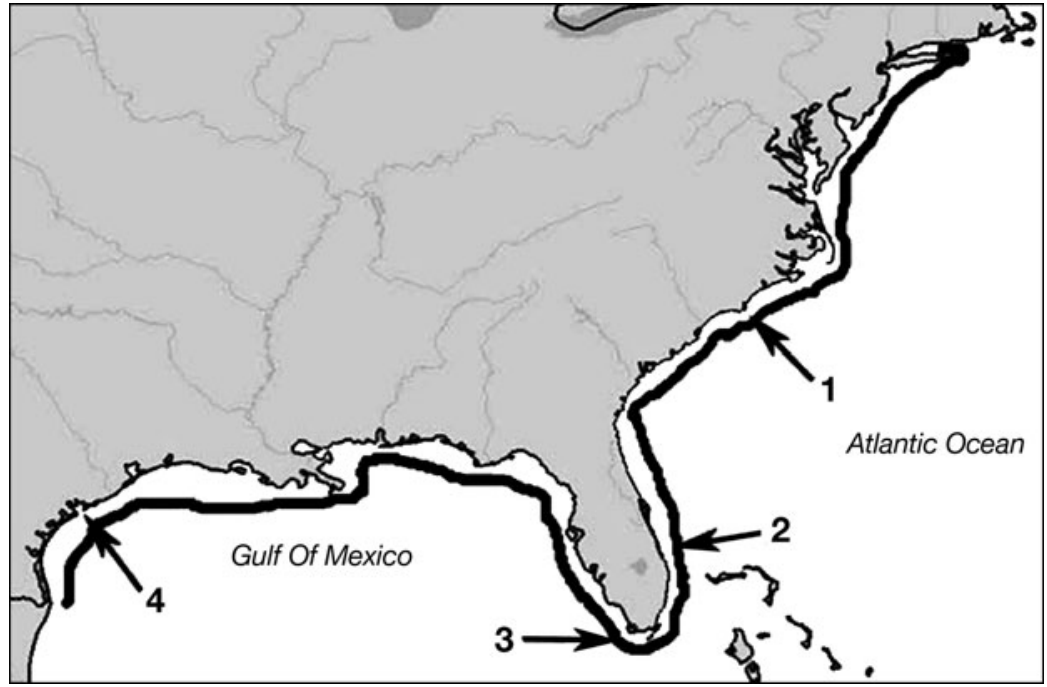

Fig. 1. Map of collection locations used in the genetic analyses (1 to 4) and interbreeding studies (2 to 4) of Lysmata wurdemanni. 1: Wilmington, North Carolina (NC); 2; Sebastian Inlet, Florida (FLE); 3: Florida Bay, Marathon Florida $(\mathrm{FLK}) ; 4$ : Port Aransas, Texas (TX). Solid line indicates known species range of Mexico and the east coast of United

States, with ranges extending from South Padre Island, Texas, to Long Island Sound, New York (Rhyne \& Lin 2006). The revision utilized live color patterns, morphology, and interbreeding experiments to differentiate between species. No interbreeding trials were conducted between populations of the 6 species of western Atlantic Lysmata.

The goal of the present study was to decipher the genetic population structure of Lysmata wurdemanni across its range to determine if the species is genetically homogeneous or consists of isolated, distinct populations. To achieve this goal we chose several populations of L. wurdemanni along its reported geographic range and compared both interbreeding results and the molecular population structure derived from the mitochondrial genes COI and 16S.

\section{MATERIALS AND METHODS}

Sample collection and preparation. Samples from 4 localities (Fig. 1) were collected with hand-nets along shallow-water rocky jetties during a nocturnal low tide at Sebastian Inlet (FLE) and Port Aransas Pass, Port Aransas, Texas (TX), with SCUBA in shallow (2 to $3 \mathrm{~m}$ ) waters at Banks Channel, Wilmington, North Carolina (NC), and in rubble or with stone crab traps at 10 to $15 \mathrm{~m}$ depth, 35 to $50 \mathrm{~km}$ NNW of Marathon, Florida in Florida Bay (FLK). Hereafter, the terms samples and populations will be used interchangeably. The sampling method was determined by habitat availability and previous knowledge of resident populations. With the exception of the NC sample (2 preserved specimens), all other samples were transported to the Vero Beach Marine Laboratory alive and housed in 801 aquaria for observation. Following $4 \mathrm{~d}$ of observation, the shrimp were given catalog numbers and moved into experimental tanks (20 l) for breeding experiments. Shrimps were fed 2 to 4 times daily an excess of a mixed diet of frozen mysid shrimp and adult brine shrimp. Entire shrimp or tissue clippings of pleopods were preserved in $95 \%$ ethanol 2 d prior to extraction of DNA, and fixed specimens were transported to the Isla Magueyes Laboratories (University of Puerto Rico, Mayagüez) for DNA processing.

Interbreeding trials. To determine reproductive compatibility, interbreeding experiments were conducted between all combinations of collected populations, except those from North Carolina (Table 1). For the remainder of the paper, reference to sex refers to the acting role of the shrimp during mating. Bauer \& Holt (1998) have thoroughly reviewed the mating system of Lysmata wurdemanni. They elegantly demonstrated that individuals of $L$. Wurdemanni are incapable of both self-fertilization and storing sperm. Females are available for mating immediately after molting and are not capable of making a mate choice because mating takes place before their soft body hardens (Bauer \& Holt 1998). Males mate prior to molting; they react to the release of a sex pheromone and mate readily with freshly molted females. L. wurdemanni requires no acclimation time to potential mates, as they generally live in groups in the wild and are opportunistic in mating. 
Table 1. Lysmata wurdemanni. Interbreeding experiments, number represents number of fertile clutches $(\mathrm{N}=6)$ produced. Sebastian Inlet, Florida (FLE); Florida Bay, Marathon Florida (FLK); Port Aransas, Texas (TX). Numbers 1 to 4 indicate degree of fertility: (1) embryo development after $24 \mathrm{~h},(2)$ retention of embryos beyond Day 5, (3) development of embryos beyond Day 10, and (4) successful larval hatching. *Low level of $F_{1}$ survival obtained; see 'Discussion'. Note: $L$. wurdemanni are euhermaphrodites; the terms male and female are used to indicate the direction of the crosses

\begin{tabular}{|lccc|}
\hline Population & FLE (male) & FLK (male) & TX (male) \\
\hline FLE (female) & $1-4$ & $1-4$ & $1-3^{*}$ \\
FLK (female) & $1-4$ & $1-4$ & $1-3^{*}$ \\
TX (female) & 1,2 & 1,2 & $1-4$ \\
\hline
\end{tabular}

The experimental layout for the interbreeding experiments consisted of 3 intra-population controls and 6 inter-population experimental crosses for each pair of populations (Table 1). Since Lysmata wurdemanni are euhermaphrodites, both male and female crosses were obtained from each pairing. Each shrimp was allowed to adjust to experimental conditions for at least a molt cycle, and the tanks were checked daily for the presence of molts. Because collection of eggs can be stressful on the shrimp, when egg masses were visually observed, a small sample was removed (approximately 50 eggs) to determine fertility. Two mortalities were observed and those individuals were replaced with shrimp from the same population in similar breeding condition. The replacement shrimp were maintained in identical conditions as those in the breeding experiments. When a shrimp molted, it was visually checked for the presence of eggs on the abdomen. The night of larval release, the shrimp was moved to a larval rearing system (Calado et al. 2003). The following data were collected using the general protocols by Fiedler (1998): (1) embryo development after $24 \mathrm{~h}$, (2) retention of embryos beyond Day 5, (3) development of embryos beyond Day 10, and (4) successful larval hatching.

Molecular analysis. DNA was isolated with the PureGene DNA isolation kit (Gentra) for fixed tissue according the manufacturer's guidelines. A portion of the mitochondrial COI and 16S genes were amplified with an Eppendorf MasterCycler. The COI region was amplified with the universal primers LCO1490 and HCO2198 (Folmer et al. 1994), and the $16 \mathrm{~S}$ region was amplified with the 1471 to 1472 primers (Crandall \& Fitzpatrick 1996). After the initial denaturation of $3 \mathrm{~min}$ at $95^{\circ} \mathrm{C}$, we programmed an anchor-PCR procedure with 10 cycles of denaturation at $95^{\circ} \mathrm{C}$ for $15 \mathrm{~s}$, annealing at $45^{\circ} \mathrm{C}\left(42^{\circ} \mathrm{C}\right.$ for $\left.16 \mathrm{~S}\right)$ for $30 \mathrm{~s}$, extension at $72^{\circ} \mathrm{C}$ for $60 \mathrm{~s}(45 \mathrm{~s}$ for $16 \mathrm{~S})$, and 25 more cycles at $50^{\circ} \mathrm{C}\left(45^{\circ} \mathrm{C}\right.$ for 16S) annealing, finishing with 5 min incubation at $72^{\circ} \mathrm{C}$. Successful PCR reactions were verified by running $5 \mu \mathrm{l}$ of the amplicon on a $1 \%$ Tris-Borate-EDTA agarose gel. Amplified bands were visualized under UV light and captured digitally. PCR reactions were cleaned of excess dNTPs, primers, and other impurities by the enzymatic treatment EXOSAP. For every $15 \mu \mathrm{l}$ of PCR product, $3 \mu \mathrm{l}$ of the EXOSAP solution were added and incubated at $37^{\circ} \mathrm{C}$ for $15 \mathrm{~min}$ and at $80^{\circ} \mathrm{C}$ for $15 \mathrm{~min}$. Sequencing reactions with each of the primers were prepared with the 3.1 BigDye Termination Kit under the following conditions: $94^{\circ} \mathrm{C}$ for $5 \mathrm{~s}$, annealing at $50^{\circ} \mathrm{C}$ for $5 \mathrm{~s}$, and extension at $60^{\circ} \mathrm{C}$ for $85 \mathrm{~s}$, repeated 60 times. Cycle sequence reactions were ethanol precipitated and loaded in either a ABI3130xl or an ABI 377 sequencing machine. DNA sequencing trace files were processed with the Phrap/Phred/Consed programs (Ewing \& Green 1998, Ewing et al. 1998, Gordon 2004) for base calling, quality assessment, and, if necessary, manual editing. Edited DNA sequences were imported into MacClade (Maddison \& Maddison 1992) for manual alignment and quality control. Aligned sequences were imported into DnaSP 4.10.9 (Rozas et al. 2003) for general statistical analysis, such as Tajima's $D$ (Tajima 1989) and Fu's Fs (Fu 1997) to test for deviation from the neutral model of molecular evolution (Kimura 1968). For population structure analysis, $F_{\mathrm{ST}}$ was calculated based on the average number of pairwise nucleotide differences within and between populations in Arlequin 3.11 (Excoffier et al. 2005). The appropriate model of nucleotide substitution for genealogical reconstruction using neighbor-joining, maximum likelihood and $F_{\mathrm{ST}}$ calculations was estimated by a hierarchical likelihood ratio test (Huelsenbeck \& Crandall 1997) in ModelTest 3.7 (Posada \& Crandall 1998). If the DNA analysis program (i.e. Arlequin 3.11) did not provide the exact model of substitution, then, the more complex, most related model was used instead. The justification for this decision is based on the nested hierarchy of DNA substitution models, where simple models are nested within more complex models. Genealogies of the sequences were reconstructed using the neighbor-joining (NJ), maximum parsimony (MP), and maximum likelihood (ML) algorithms in PAUP* (Swofford 2002). Heuristic searches in MP reconstruction were performed using 10 random addition replicates with nearest neighbor interchange (NNI) branch swapping. Heuristic searches in ML reconstruction were performed as follows: starting tree(s) obtained via stepwise addition, random addition of sequences, 10 replicates, and tree bisection-reconnection (TBR) as the branch-swapping algorithm. Robustness of clades was evaluated with 1000 (MP and NJ) and 100 bootstrap replications (ML) (Felsenstein 1985). Lysmata pederseni was used as the outgroup in both gene trees. 


\section{RESULTS}

\section{Interbreeding trials}

Of the 3 populations tested during interpopulation breeding trials, 2 crosses failed to produce embryos that survived beyond Day 5 . These 2 failed crosses occurred between the TX female shrimps and FLK or FLE male shrimps (Table 1). In these crosses, egg number was visibly reduced from normal fertilization (only a few hundred eggs as opposed to normal mating yields in which there is a full abdomen of eggs, often bulging out beyond the pleopods). Additionally, crosses between FLE or FLK females and TX males produced embryos that survived beyond Day 10; however, they were not subsequently viable as no larvae were produced. These embryos were characterized by having a higher than normal rate of mortality. While the embryos were not removed and counted, a noticeable number of embryos in these crosses appeared to be bacterially infected (indicated by a dark brown color). All other crosses produced viable larvae (Table 1).

\section{Molecular analysis}

A $540 \mathrm{bp}$ portion of COI and a $497 \mathrm{bp}$ portion of $16 \mathrm{~S}$ were used for analysis after editing and trimming the DNA sequences. The resulting $16 \mathrm{~S}$ segment of Lysmata pederseni was 4 bases longer than the $16 \mathrm{~S}$ segment of $L$. wurdemanni. No insertions or deletions of amino acids in COI were found within the 4 populations of $L$. wurdemanni. There were no stop codons present in the amino acid translation, and no sequences contained double bands in both the forward and reverse reactions. Additionally, BLAST searches indicated that the closest hits were previously published sequences from related species of shrimps. Altogether, these results provide a high level of confidence that the sequences are mtDNA and not pseudogenes. The molecular data will be presented gene-by-gene, as a few shrimps did not yield a DNA sequence because of PCR and sequencing failures.

Sequence data from COI and $16 \mathrm{~S}$ regions were obtained for shrimps from 4 localities/populations resulting in 17 (COI; Table 2) and 8 distinct haplotypes (16S; Table 3), respectively. Shrimps from the 4 sampling locations shared no haplotypes (except FLE and NC in $16 \mathrm{~S}$; Tables 2 \& 3), but the nucleotide diversity within locations was low. Nucleotide diversity levels of COI/16S were estimated for NC $(\pi=0 / 0)$, FLE $(\pi=0.00446 /$ $0.00073)$, FLK $(\pi=0.00086 / 0.00106)$, and TX $(\pi=$ $0.00365 / 0)$. Tajima's $D$ and Fu's Fs statistics did not reveal genetic patterns inconsistent with DNA neutrality for COI or $16 \mathrm{~S}$, indicating that the chosen genes are evolving neutrally and are therefore appropriate for pop-
Table 2. Lysmata wurdemanni. Haplotype distribution of COI by locality (total number of individuals sampled). Numbers indicate the number of individuals at each locality (see Fig. 1) with a specific haplotype

\begin{tabular}{|lcc|}
\hline & Haplotype & $\mathrm{n}$ \\
\hline FLK (13) & 1 & 10 \\
& 2 & 1 \\
& 3 & 1 \\
FLE (12) & 4 & 1 \\
& 5 & 1 \\
& 6 & 2 \\
& 7 & 2 \\
& 8 & 2 \\
NC (2) & 9 & 1 \\
TX (8) & 10 & 4 \\
& 11 & 2 \\
& 12 & 1 \\
& 13 & 2 \\
& 14 & 1 \\
& 16 & 1 \\
& 17 & 1 \\
\hline
\end{tabular}

Table 3. Lysmata wurdemanni. Haplotype distribution of $16 \mathrm{~S}$ by locality (total number of individuals sampled). Numbers indicate the number of individuals at each locality (see Fig. 1) with a specific haplotype

\begin{tabular}{|lcr|}
\hline & Haplotype & $\mathrm{n}$ \\
\hline FLK (8) & 2 & 6 \\
& 3 & 1 \\
& 4 & 1 \\
FLE (17) & 5 & 1 \\
& 6 & 14 \\
& 7 & 1 \\
NC (1) & 8 & 1 \\
TX (10) & 6 & 1 \\
& 1 & 10 \\
\hline
\end{tabular}

ulation level inferences for Lysmata wurdemanni (data not shown). Nucleotide substitutions in COI within and among populations were all synonymous, occurring in the third and first codon positions. These substitutions consisted of 62 transitions (5 singletons) and 13 transversions. Three non-synonymous substitutions were recorded in $L$. pederseni, resulting in 3 amino acid differences compared to $L$. wurdemanni. There were 29 transitions and 16 transversions in the $16 \mathrm{~S}$ sequences of $L$. wurdemanni. Genealogical trees were constructed in PAUP using HKY (Hasegawa-Kishino-Yano model of substitution) as the most appropriate model of substitution for both COI [Base $=(0.2605,0.2198,0.1845), \mathrm{Nst}=2$, TRatio $=5.6887, \Gamma=0.1911]$, and 16S $[$ Base $=(0.3125$, 
$0.1364,0.2260)$, Nst $=2$, TRatio $=1.9648]$. Phylogenetic analysis of the COI and 16S data, in combination or separately, support a strong divergence between all populations, except NC and FLE, in which NC haplotypes were nested inside the FLE clade (Figs. 2 \& 3). The extremely high $F_{\text {ST }}$ statistics (Table 4), genealogical analysis (Figs. 2 \& 3), and the COI parsimony network (Fig. 4) underline the distinct nature of the sampled populations of L. wurdemanni. These analyses demonstrated a lack of gene flow and strong isolation between all populations, except those on the east coast of the United States. There was a surprisingly large divergence $3.23 \%$ for COI and $2.55 \%$ for $16 \mathrm{~S}$, on average, 17.3 and 11.9 substitutions, respectively; Table 4 ) between the 2 populations in Florida, even though the locations are separated by only $\sim 450 \mathrm{~km}$ and strong north-bound currents (Florida Current and Gulf Stream) exist within $50 \mathrm{~km}$ of the FLK and FLE populations. The highest divergence was observed in COI between the TX and the FLE and NC populations ( $>10 \%, 54$ to 56 substitutions), followed by the

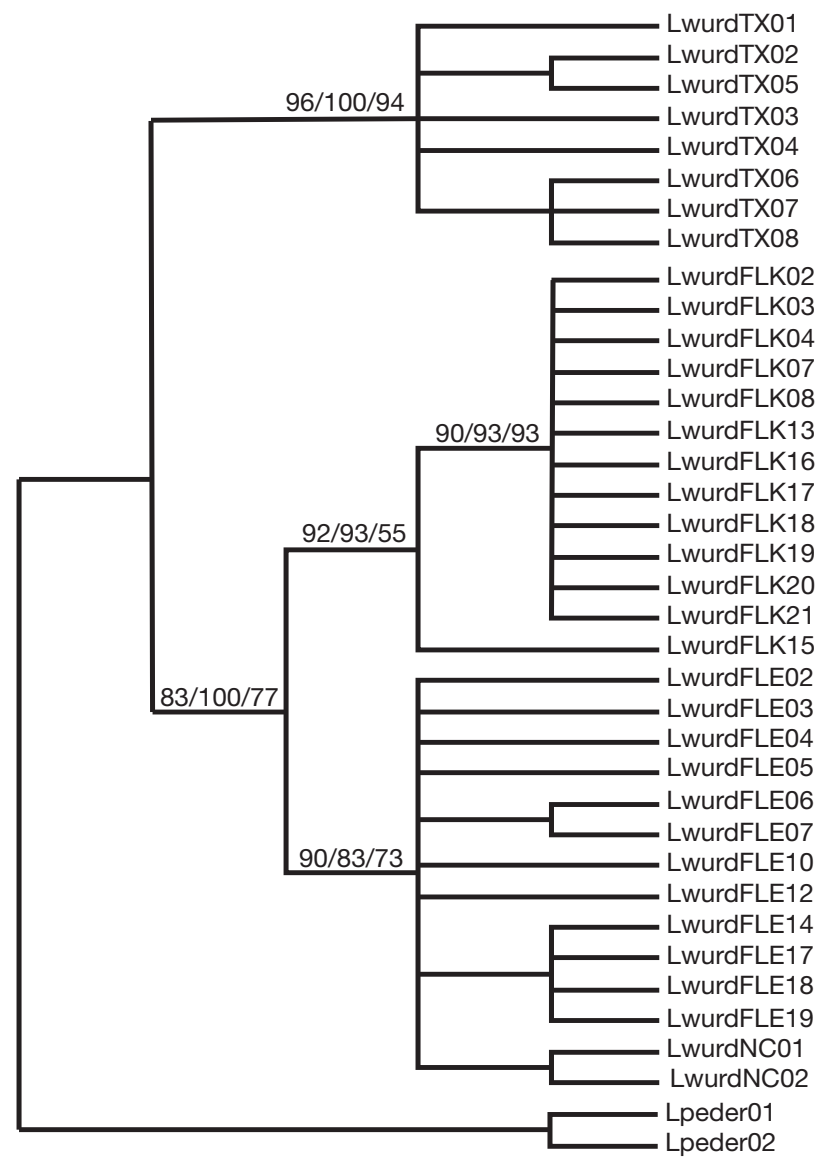

Fig. 2. Lysmata wurdemanni. The $50 \%$ majority rule genealogical tree constructed with maximum-likelihood based on cytochrome oxidase subunit I (COI) sequences. Bootstrap values are presented for maximum-likelihood/maximumparsimony/neighbor-joining analyses. Bootstrap values within the major clades have been deleted for clarity

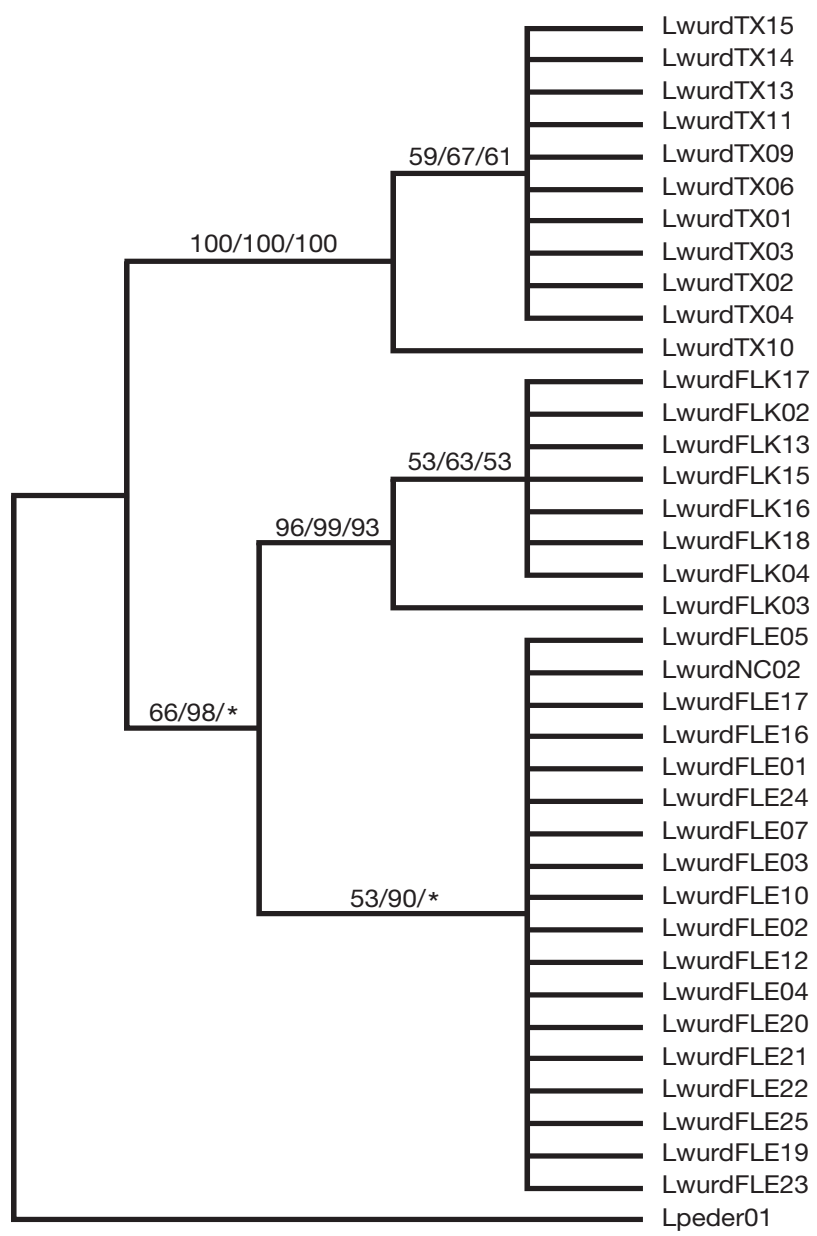

Fig. 3. Lysmata wurdemanni. The $50 \%$ majority rule genealogical tree constructed with maximum likelihood based on 16S sequences. Bootstrap values are presented for ML/MP/NJ analyses. * Bootstrap values $<50 \%$

Table 4. Lysmata wurdemanni. Average number of nucleotide differences between populations, divergence, and pairwise $F_{\mathrm{ST}}$ statistics for the COI/16S genes sequenced from 4 different populations; Wilmington, North Carolina (NC); Sebastian Inlet, Florida (FLE); Florida Bay, Marathon, Florida (FLK); and Port Aransas, Texas (TX). Average numbers of nucleotide differences and percentages of divergence were calculated in DNAsp. $F_{\mathrm{ST}}$ calculations were carried out with Arlequin, using Tamura-Nei distance (Tamura \& Nei 1993; TrN). The specific settings were $\operatorname{TrN}+\Gamma(0.2)+$ TRatio $=5$ for COI and $\operatorname{TrN}+$ TRatio $=2$ for $16 \mathrm{~S}$. na: no tests were performed since only $1 \mathrm{NC}$ sequence was available

\begin{tabular}{|c|c|c|c|}
\hline & $\begin{array}{l}\text { Average nos. } \\
\text { of nucleotide } \\
\text { differences }\end{array}$ & Divergence (\%) & $F_{\mathrm{ST}}$ \\
\hline $\mathrm{FLE} \times \mathrm{NC}$ & $2.83(0.2)$ & $0.52(0.04)$ & 0.336 (na) \\
\hline FLE $\times$ FLK & $17.3(11.9)$ & $3.23(2.55)$ & $0.936(0.967)$ \\
\hline $\mathrm{FLE} \times \mathrm{TX}$ & $54.8(33.1)$ & $10.15(6.83)$ & $0.973(0.994)$ \\
\hline FLK × NC & $16.9(11.7)$ & $3.15(2.49)$ & 0.976 (na) \\
\hline $\mathrm{FLK} \times \mathrm{TX}$ & $51.0(38.0)$ & $9.51(8.09)$ & $0.986(0.995)$ \\
\hline $\mathrm{TX} \times \mathrm{NC}$ & $56.0(33.0)$ & 10.37 (6.65) & 0.980 (na) \\
\hline
\end{tabular}




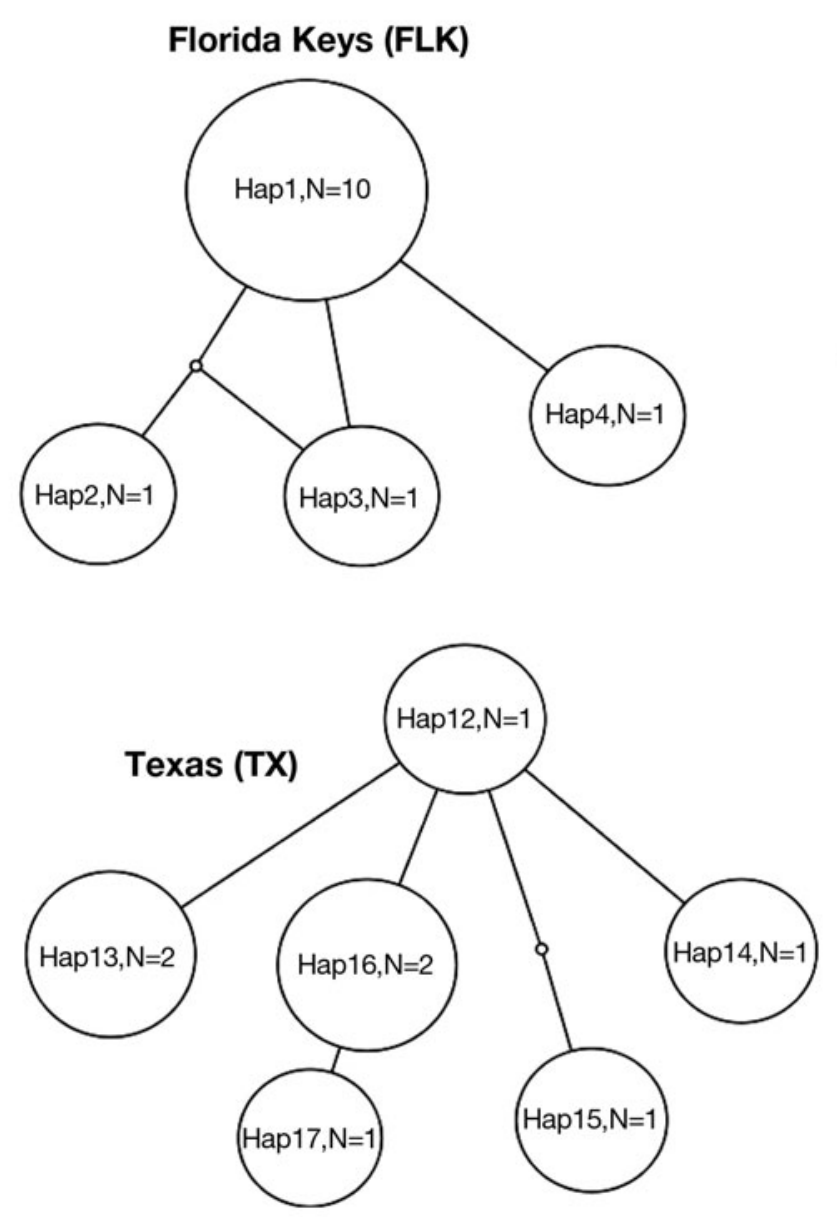

Texas-Florida Keys divergence (9.5\%, 51 substitutions). FLE populations are closely related to NC populations (about $0.5 \%$, 3 substitutions); however, the populations are indistinguishable with the $16 \mathrm{~S}$ data. This is not surprising since $16 \mathrm{~S}$ is regarded as a more conservative gene than COI and is routinely used for higher level phylogenetic studies (e.g. Braga et al. 1999, Goetze 2003, Porter et al. 2005). DNA sequences have been deposited in GenBank under Accession Numbers EU135796 to EU135869.

\section{DISCUSSION}

Lysmata wurdemanni has an extended planktonic larval stage, with $\geq 21 \mathrm{~d}$ in the water column and up to $90 \mathrm{~d}$ under less than ideal conditions in the laboratory (A. L. Rhyne \& D. Zhang unpubl. data). The mitochondrial sequences delineate a striking separation between populations at multiple points along the species' geographic range. This strongly supports an unrealized larval dispersal potential in the species. Popula-

\section{Florida east coast (FLE)}

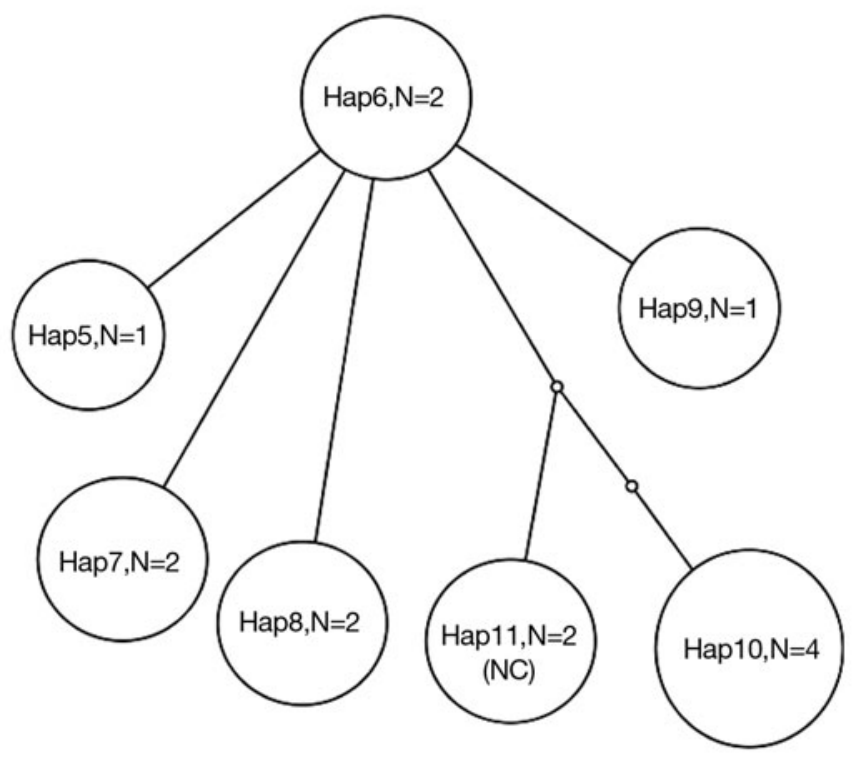

Fig. 4. Lysmata wurdemanni. Parsimony haplotype network based on COI sequences. Each large circle represents a unique haplotype. The haplotype identification number and the number of specimens sharing each haplotype are indicated within each circle. The minimum number of steps is represented by the small empty circles between each haplotype. Closed loops represent homoplasy, as indicated by the statistical parsimony analysis

tions that are a few hundred kilometers apart were significantly differentiated. Gene flow was absent across the geographic range of the species, with the possible exception of populations from the east coast of the United States. Because the sample size was small from the North Carolina population, inferences on the connectivity between the Florida east coast and those to the north, presumably connected by the Gulf Stream, are preliminary at the present time. Given the limited number of available specimens, there were no shared haplotypes between the North Carolina and Florida populations for COI (Fig. 4). An extended survey of populations along the east coast, coupled with a larger number of samples, will most likely result in shared haplotypes between these populations. Since COI is usually more variable than $16 \mathrm{~S}$, it is not surprising that the single $16 \mathrm{~S}$ haplotype from the NC population was identical to one of the haplotypes sequenced from FLE (Table 3). The divergence measured between the 2 populations on the east coast of the United States was extremely low $(0.5 \%$ in COI, absent in $16 \mathrm{~S})$, when compared to that between other populations. 
The complete lack of gene flow between populations within Florida was surprising given the close proximity to strong east- then north-bound currents in the Florida Keys, and the long larval duration in the water column. One might have expected the populations to be connected in a stepping-stone fashion, with limited or no genetic connectivity between the northern and southern populations of Florida. However, the data strongly support a series of subdivided populations. Given the geographic distance between the populations, population differentiation was expected between Texas and all other populations surveyed, but not between the 2 Floridian locations. The high level of divergence $(>10 \%)$, coupled with unsuccessful hybridization (Table 1) between Texas and Florida populations, verifies that comparison of COI genes provides an acceptable level of resolution to distinguish unique populations. At the same time populations with $<3 \%$ divergence readily interbreed without any modality. Although no experimental data were available, it is very likely that shrimp from Florida could readily interbreed with shrimp from North Carolina.

The Texan population demonstrated a high level of mitochondrial DNA divergence relative to the other populations and low interbreeding ability with other populations. During interbreeding experiments, the Texas shrimps failed to outcross with other populations. The modality observed is interesting given that this species is a simultaneous hermaphrodite and shrimp were used in both male and female roles. Additional breeding experiments will have to be conducted using a higher replicate number to confirm that there is a total lack of interbreeding ability between Texas populations and those found in Florida. In the genus Lysmata it is common for bacterial infections to spread from dead embryos to compromise viable eggs; in addition the presence of eggs on a molt is an indication of high bacterial levels or stress on the female (A. L. Rhyne unpubl. obs.). These factors must be considered when determining if viable offspring can be produced. The results of the present study demonstrate both a difference in viability that is dependent on the modality of the cross and a disconnection between the interbreeding ability of populations and a high level of molecular divergence.

A high level of divergence is not unexpected when compared to other studies in the literature (for review see Avise 2004). A number of species have displayed a high degree of separation between the Gulf of Mexico and eastern Florida populations (Saunders et al. 1986, Reeb \& Avise 1990, Vogler \& DeSalle 1993, 1994, Schizas et al. 1999). These examples are not limited to species with low dispersal ability or sessile adult populations. The black sea bass Centropristis striata has been shown to exhibit a distinct mtDNA break between the Atlantic and Gulf populations (Bowen \& Avise 1990). Some decapod species have established differences between the Gulf of Mexico and Atlantic Ocean populations. For example, the crab genera Uca and Sesarma both display 'trans-Floridian' species complexes (Felder \& Staton 1994). These differences are most likely due to vicariant distribution, associated with the emergence of the Florida Peninsula during past glaciation events. Felder \& Staton (1994) surmised that these 'populations' were in fact sister taxa, as reflected by the fact that species of both genera display remarkable differences in coloration pattern throughout their range. Other studies have reported less divergence between Gulf of Mexico and Florida populations. For example, the blue crab Callinectes sapidus displays a certain level of population structure over a wide geographic range, but lacks the degree of divergence observed in other species (McMillen-Jackson \& Bert 2004). In Lysmata wurdemanni, every sampled population is distinct; the highest degrees of divergence were observed between the Texas population and those in Florida and North Carolina ( 10\% in COI). While this might suggest a cryptic species complex, interbreeding results demonstrate speciation in progress. Other crustaceans, such as the tidepool copepod Tigriopus californicus, exhibit even higher divergence (17 to $22 \%$ in COI) between central and southern Californian populations (Burton \& Lee 1994, Burton 1998), but can still interbreed. There is still the possibility that hybridization between Florida Keys and Texas populations results in $\mathrm{F}_{2}$ breakdown, similar to hybrid breakdown observed after the first generation in the copepod Eurytemora affinis (Lee 2000). Additional sampling of $L$. wurdemanni may identify reproductively incompatible populations resembling the degree of genetic differentiation and reproductive incompatibility observed between some southern California and Mexican populations of $T$. californicus (Ganz \& Burton 1995).

Sequence divergence at the mtDNA level has been used to infer reproductive isolation between closely related species. Knowlton et al. (1993) established that a divergence $>6 \%$ in COI sequences suffices to produce reproductive isolation in the snapping shrimp Alpheus. The present study fails to find total reproductive isolation at $\sim 10 \%$ divergence. However, comparisons of the amount of genetic divergence necessary for hybrid breakdown may not be appropriate between phylogenetically different taxa. Additionally, the stochasticity associated with coalescence times in mitochondrial genes is high (Hudson \& Turelli 2003), and predictions or extrapolations based on a single gene may be highly inaccurate.

One of our a priori expectations was that the shrimps from the Florida Keys, which were collected in Florida 
Bay, would be genetically similar to the other Floridian samples given that the Florida Current and Gulf Stream are close to the sampling areas. It now seems possible that Lysmata wurdemanni larvae in Florida Bay do not enter the Florida Current. Higher resolution sampling will be required to elucidate the dynamics of the population structure within the Florida Keys and to determine whether gene flow in this small geographic area is extensive or is limited, resulting in population subdivision along the eastern Florida coast. Perhaps there are several distinct populations within the Florida Keys and Florida Bay, where Florida Bay is disconnected from the Florida Keys and populations in Florida Bay are related to those in western Florida. Other marine taxa, such as the blue mussel Mytilus edulis have long-living larval stages, but the larval dispersal is limited to $10 \mathrm{~s}$ of kilometers in southwest England (Gilg \& Hilbish 2003). If the realized dispersal of $L$. wurdemanni is similar to that of $M$. edulis, then the significant population structure of $L$. wurdemanni could be explained and additional distinct populations should be expected. There are L. wurdemanni shrimp in the Florida Keys that exist in very close proximity to the Florida Current. Rhyne \& Lin (2006) discuss the presence of several species of Lysmata occupying small rock ledges around the Key West Lakes, a small group of mangrove islands west of Key West, which is subdivided by the Northwest and Boca Grand Channels. This population could broadcast larvae into both the Gulf of Mexico and the Atlantic Ocean, and larvae would be expected to easily migrate out to the Florida Current. A population at this locality might hold the key to unlocking a possible genetic connectivity between populations of the Florida Bay and those along the eastern United States coast. Given that significant Gulf Stream transport is expected for populations along the eastern Florida coast and the southeastern United States, it is possible that populations along the east coast are the least divergent $(0.56 \%)$.

There has been a great deal of attention paid to population connectivity in recent literature (Palumbi 2003, Cowen et al. 2006, Becker et al. 2007). This is primarily due to the importance of gene flow to the conservation and biodiversity of marine systems (Cowen et al. 2006). Studies have focused on the need to understand population structure before establishing marine reserves for the purpose of maintaining viable local populations. In the present study, Lysmata wurdemanni, a highly traded decapod in the marine aquarium industry, exhibits a significant genetic structure comprised of 3 distinct mitochondrial lineages at a large geographical scale. Restricted or closed populations are highly susceptible to local fishing pressures; thus, they must be managed differently from those with open populations. The population in Florida Bay is re-supplied by local recruitment and probably by other adjacent populations from the eastern Gulf of Mexico that were not sampled. Given that this population is under intense fishing pressure, with little to no fishery management, steps should be taken to control the exploitation of this species. Sound management plans for marine ornamental species should thus use information from genetic studies identifying species comprised of several restricted populations.

Beyond applications to fishery management, the present study provides an opportunity to use Lysmata wurdemanni as a model for species with long larval durations. Because there are several modes of larval development within the genus Lysmata, the population structure of additional species should also be examined. The closely related species L. boggessi Rhyne \& Lin, 2006 and L. pederseni Rhyne \& Lin, 2006 provide an interesting genetic comparison to L. wurdemanni because of their somewhat overlapping distribution (e.g. L. boggessi) or obligate symbiosis with tube sponges (e.g. L. pederseni).

In conclusion, Lysmata wurdemanni displays a marked population structure among the sampled locations, despite having an extended planktonic larval stage and a large reproductive capacity. The molecular data are consistent with the Gulf of Mexico/Florida genetic disconnection reported in several intertidal marine species (Roberts 1997). Our data support the distinctiveness of the Texas population as a subspecies or sibling species compared to those found in Florida or on the east coast of the United States. The role of the FLK populations remains unclear, and the inclusion of more populations, especially from the eastern Gulf of Mexico, is required in order to unravel the distribution of each genetically distinct population. It is likely that the populations along the northwestern Florida coast could be closely related to those in Texas through a series of stepping stones or that there are other intermediate populations between Florida and Texas maintained by highly localized recruitment. Both outcomes have a significant impact on the evolutionary genetics and the conservation of this species.

Acknowledgements. The authors are grateful to M. Wittenrich, H. Fatzinger, and E. Pedersen for their help in collecting shrimp specimens. H. Torrés-Pratts, J. Garcia, and D. Ruiz provided assistance in processing the samples. Comments from 4 reviewers improved the quality of the manuscript. D. Ballantine and M. DiMaggio improved the language of the manuscript. Funding for this project was provided by the 2007 Arts and Sciences Seed Money of UPRM and a Caribbean Coral Reef Institute grant awarded to N.V.S. DNA sequencing was performed in the Sequencing and Genotyping facility, University of Puerto Rico-Río Piedras, which is supported in part by NCRR AABRE Grant No. P20 RR16470, NIH-SCORE Grant No. S06GM08102, University of Puerto Rico Biology Department, NSF-CREST Grant No. 0206200. 


\section{LITERATURE CITED}

Almany GR, Berumen ML, Thorrold SR, Planes S, Jones GP (2007) Local replenishment of coral reef fish populations in a marine reserve. Science 316:742-744

Anger A (2001) The biology of decapod crustacean larvae. In: Vonk R (ed) Crustacean issues, Vol 14. A. A. Balkema Publishers, Lisse

Avise JC (2004) Molecular markers, natural history and evolution. Sinauer, Sunderland, MA

Barber PH (1999) Patterns of gene flow and population genetic structure in the canyon treefrog, Hyla arenicolor (Cope). Mol Ecol 8:563-576

Bauer RT (2000) Simultaneous hermaphroditism in caridean shrimps: a unique and puzzling sexual system in the Decapoda. J Crustac Biol 20:116-128

Bauer RT (2004) Remarkable shrimps: natural history and adaptations of the carideans. University of Oklahoma Press, Norman, OK

Bauer RT, Holt GJ (1998) Simultaneous hermaphroditism in the marine shrimp Lysmata wurdemanni (Caridea: Hippolytidae): an undescribed sexual system in the decapod Crustacea. Mar Biol 132:223-235

Baums IB, Paris CB, Cherubin LM (2006) A bio-oceanographic filter to larval dispersal in a reef-building coral. Limnol Oceanogr 51:1969-1981

Becker BJ, Levin LA, Fodrie FJ, McMillan PA (2007) Complex larval connectivity patterns among marine invertebrate populations. Proc Natl Acad Sci USA 104:3267-3272

Bird CE, Holland BS, Bowen BW, Toonen RJ (2007) Contrasting phylogeography in three endemic Hawaiian limpets (Cellana spp.) with similar life histories. Mol Ecol 16: 3173-3186

Bohonak AJ (1999) Dispersal, gene flow and population structure. Q Rev Biol 74:21-45

Bowen BW, Avise JC (1990) Genetic structure of Atlantic and Gulf of Mexico populations of sea bass, menhaden, and sturgeon: influence of zoogeographic factors and lifehistory patterns. Mar Biol 107:371-381

> Braga E, Zardoya R, Meyer A, Yen J (1999) Mitochondrial and nuclear rRNA based copepod phylogeny with emphasis on the Euchaetidae (Calanoida). Mar Biol 133:79-90

Burton RS (1998) Intraspecific phylogeography across the Point Conception biogeographic boundary. Evolution 52: 734-745

Burton RS, Feldman MW (1982) Population genetics of coastal and estuarine invertebrates: Does larval behavior influence population structure? In: Kennedy VS (ed) Estuarine comparisons. Academic Press, New York

Burton RS, Lee BN (1994) Nuclear and mitochondrial gene genealogies and allozyme polymorphism across a major phylogeographic break in the copepod Tigriopus californicus. Proc Natl Acad Sci USA 91:5197-5201

> Calado R, Narciso L, Morais S, Rhyne AL, Lin J (2003) A rearing system for the culture of ornamental decapod crustacean larvae. Aquaculture 218:329-339

Calado R, Figueiredo J, Rosa R, Nunes ML, Narciso L (2005) Larval culture of Monaco shrimp Lysmata seticaudata (Decapoda: Hippolytidae): effect of temperature, rearing density and larval diet. Aquaculture 245:221-237

Cowen RK, Paris CB, Srinivasan A (2006) Scaling of connectivity in marine populations. Science 311:522-527

> Crandall KA, Fitzpatrick Jr JF (1996) Crayfish molecular systematics: inferences using a combination of procedures to estimate phylogeny. Syst Biol 45:1-26

Ewing B, Green P (1998) Basecalling of automated sequencer traces using phred. II. Error probabilities. Genome Res 8: 186-194
Ewing B, Hillier L, Wendl M, Green P (1998) Basecalling of automated sequencer traces using phred. I. Accuracy assessment. Genome Res 8:175-185

Excoffier L, Laval G, Schneider S (2005) Arlequin Ver. 3.0: an integrated software package for population genetics data analysis. Evol Bioinform Online 1:47-50

Felder DL, Staton JL (1994) Genetic differentiation in transFloridian species complexes of Sesarma and Uca (Decapoda: Brachyura). J Crustac Biol 14:191-209

Felsenstein J (1985) Confidence limits on phylogenies: an approach using bootstrap. Evolution 39:783-791

Fiedler GC (1998) Functional, simultaneous hermaphroditism in female phase Lysmata amboinensis (Decapoda: Caridea: Hippolytidae). Pac Sci 52:161-169

Folmer O, Black M, Hoen W, Lutz R, Vrijenhoek R (1994) DNA primers for amplification of mitochondrial cytochrome $c$ oxidase subunit I from diverse metazoan invertebrates. Mol Mar Biol Biotechnol 3:294-299

Fu YX (1997) Statistical tests of neutrality of mutations against population growth, hitchhiking and background selection. Genetics 147:915-925

Ganz HH, Burton RS (1995) Genetic differentiation and reproductive incompatibility among Baja California populations of the copepod Tigriopus californicus. Mar Biol 123: 821-827

Gilg MR, Hilbish TJ (2003) The geography of marine larval dispersal: coupling genetics with fine-scale physical oceanography. Ecology 84:2989-2998

> Goetze E (2003) Cryptic speciation on the high seas; global phylogenetics of the copepod family Eucalanidae. Proc R Soc Lond B Biol Sci 270:2321-2331

Gómez S, Fleeger JW, Rocha-Olivares A, Foltz D (2004) Four new species of Cletocamptus Schmankewitsch, 1875, closely related to Cletocamptus deitersi (Richard, 1897) (Copepoda: Harpacticoida). J Nat Hist 38:2669-2732

Gordon D (2004) Viewing and editing assembled sequences using consed. In: Baxevanis AD, Davison DB (eds) Current protocols in Bioinformatics. John Wiley, New York

Gore R (1985) Molting and growth in decapod larvae. In: Wenner A (ed) Larval growth. Balkema, Rotterdam

> Hilbish TJ (1996) Population genetics of marine species: the interaction of natural selection and historically differentiated populations. J Exp Mar Biol Ecol 200:67-83

Hilbish TJ, Koehn RK (1985) The physiological basis of natural selection at the LAP locus. Evolution 39:1302-1317

- Hudson RR, Turelli M (2003) Stochasticity overrules the "three times rule": genetic drift, genetic draft, and coalescence times for nuclear loci versus mitochondrial DNA. Evolution 57:182-190

Huelsenbeck JP, Crandall KA (1997) Phylogeny estimation and hypothesis using maximum likelihood. Annu Rev Ecol Syst 28:437-466

Jablonksi D (1986) Larval ecology of macroevolution in marine invertebrates. Bull Mar Sci 39:565-587

> Jones GP, Milicich MJ, Emslie MJ, Lunow C (1999) Self recruitment in a coral-reef fish population. Nature 402: 802-804

Kelly RP, Eernisse DJ (2007) Southern hospitality: a latitudinal gradient in gene flow in the marine environment. Evolution 61:700-707

> Kimura M (1968) Evolutionary rate at the molecular level. Nature 217:624-626

Kinlan BP, Gaines SD (2003) Propagule dispersal in marine and terrestrial environments: a community perspective. Ecology 84:2007-2020

> Knowlton N (1993) Sibling species in the sea. Annu Rev Ecol Syst 24:189-216 
Knowlton N, Keller BD (1986) Larvae which fall far short of their potential—highly localized recruitment in an alpheid shrimp with extended larval development. Bull Mar Sci 39:213-223

Knowlton N, Weigt LA (1998) New dates and new rates for divergence across the Isthmus of Panama. Proc R Soc Lond B Biol Sci 265:2257-2263

Knowlton N, Weigt LA, Solórzano LA, Mills DK, Bermingham E (1993) Divergence in proteins, mitochondrial DNA, and reproductive compatibility across the Isthmus of Panama. Science 260:1629-1632

> Lee CE (2000) Global phylogeography of a cryptic copepod species complex and reproductive isolation between genetically proximate 'populations'. Evolution 54: 2014-2027

Lee T, Foighil DÓ (2004) Hidden Floridian biodiversity: mitochondrial and nuclear gene trees reveal four cryptic species within the scorched mussel, Brachidontes exustus, species complex. Mol Ecol 13:3527-3542

Lee T, Foighil DÓ (2005) Placing the Floridian marine genetic disjunction into a regional evolutionary context using the scorched mussel, Brachidontes exustus, species complex. Evolution 59:2139-2158

> Lester SE, Ruttenberg BI (2005) The relationship between pelagic larval duration and range size in tropical reef fishes: a synthetic analysis. Proc R Soc Lond B Biol Sci 272: 585-591

Maddison WP, Maddison DR (1992) MacClade: analysis of phylogeny and character evolution. Sinauer, Sunderland, MA

Mathews LM (2006) Cryptic biodiversity and phylogeographical patterns in a snapping shrimp species complex. Mol Ecol 15:4049-4063

Mathews LM, Schubart CD, Neigel JE, Felder DL (2002) Genetic, ecological, and behavioural divergence between two sibling snapping shrimp species (Crustacea: Decapoda: Alpheus). Mol Ecol 11:1427-1437

McConaugha JR (1992) Decapod larvae: dispersal, mortality, and ecology. A working hypothesis. Am Zool 32: 512-523

McMillen-Jackson AL, Bert TM (2004) Mitochondrial DNA variation and population genetic structure of the blue crab Callinectes sapidus in the eastern United States. Mar Biol 145:769-777

Palumbi SR (1994) Genetic divergence, reproductive isolation, and marine speciation. Annu Rev Ecol Syst 25: $547-572$

Palumbi SR (2003) Population genetics, demographic connectivity, and the design of marine reserves. Ecol Appl 13: 146-158

Porter ML, Pérez-Losada M, Crandall KA (2005) Model-based multi-locus estimation of decapod phylogeny and divergence times. Mol Phylogenet Evol 37:355-369

Posada D, Crandall KA (1998) Modeltest: testing the model of DNA substitution. Bioinformatics 14:817-818

Reeb CA, Avise JC (1990) A genetic discontinuity in a continuously distributed species: mitochondrial DNA in the American oyster, Crassostrea virginica. Genetics 124: 397-406

Rhyne AL, Lin J (2006) A western Atlantic peppermint shrimp complex: redescription of Lysmata wurdemanni, descrip-

Editorial responsibility: Gretchen Hofmann,

Santa Barbara, California, USA tion of four new species, and remarks on Lysmata rathbunae (Crustacea: Decapoda: Hippolytidae). Bull Mar Sci 79:165-204

> Roberts CM (1997) Connectivity and management of Caribbean coral reefs. Science 278:1454-1457

Rocha-Olivares A, Fleeger JW, Foltz DW (2001) Decoupling of molecular and morphological evolution in deep lineages of a meiobenthic harpacticoid copepod. Mol Biol Evol 18: 1088-1102

Rozas J, Sánchez-DelBarrio JC, Messeguer X, Rozas R (2003) DnaSP: DNA polymorphism analyses by the coalescent and other methods. Bioinformatics 19:2496-2497

Saunders NC, Kessler LG, Avise JC (1986) Genetic variation and geographic differentiation in mitochondrial DNA of the horseshoe crab, Limulus polyphemus. Genetics 112: 613-627

Schizas NV, Street GT, Coull BC, Chandler GT, Quattro JM (1999) Molecular population structure of the benthic copepod Microarthridion littorale along the southeastern and gulf coasts of the United States. Mar Biol 135:399-405

Schizas NV, Chandler GT, Coull BC, Klosterhaus SL, Quattro JM (2001) Differential survival of three mitochondrial lineages in a marine copepod exposed to a mixture of pesticides. Environ Sci Technol 35:535-538 .

Shuto T (1974) Larval ecology of prosobranch gastropods and its bearing on biogeography and paleontology. Lethaia 7: $239-256$

Sotka EE, Wares JP, Barth JA, Grosberg RK, Palumbi SR (2004) Strong genetic clines and geographical variation in gene flow in the rocky intertidal barnacle Balanus glandula. Mol Ecol 13:2143-2156

Swofford DL (2002) PAUP*: phylogenetic analysis using parsimony ( ${ }^{*}$ and other methods). Sinauer Associates, Sunderland, MA

Tajima F (1989) Statistical method for testing the neutral mutation hypothesis by DNA polymorphism. Genetics 105:437-460

Tamura K, Nei M (1993) Estimation of the number of nucleotide substitutions in the control region of mitochondrial DNA in humans and chimpanzees. Mol Biol Evol 10: 512-526

Taylor MS, Hellberg ME (2003) Genetic evidence for local retention of pelagic larvae in a Caribbean reef fish. Science 299:107-109

Vogler AP, DeSalle R (1993) Mitochondrial DNA evolution and the application of the phylogenetic species concept in the Cicindela dorsalis complex (Coleoptera: Cicindelidae). In: Desender K (ed) Carabid beetles: ecology and evolution. Kluwer Academic Publishers, Dordrecht

> Vogler AP, DeSalle R (1994) Evolution and phylogenetic information content of the ITS-1 region in the tiger beetle Cicindela dorsalis. Mol Biol Evol 11:393-405

Wares JP, Gaines SD, Cunningham CW (2001) A comparative study of asymmetric migration events across a marine biogeographic boundary. Evolution 55:295-306

Wise JB, Harasewych G, Dillon R (2004) Population divergence in the sinistral Busycon whelks of North America, with special reference to the east Florida ecotone. Mar Biol 145:1167-1179

Submitted: February 29, 2008; Accepted: April 9, 2009

Proofs received from author(s): July 20, 2009 